CZASOPISMO INŻYNIERII LA¿OWEJ, ŚRODOWISKA I ARCHITEKTURY JOURNAL OF CIVIL ENGINEERING, ENVIRONMENT AND ARCHITECTURE

JCEEA, t. XXXIV, z. 64 (4///17), październik-grudzień 2017, s. 115-122, DOI:10.7862/rb.2017.197

\author{
Adriana ESTOKOVA ${ }^{1}$ \\ Michaela SMOLAKOVA ${ }^{2}$ \\ Alena LUPTAKOVA ${ }^{3}$
}

\title{
TRENDS OF Co AND Mn LEACHING FROM SLAG MORTARS
}

\begin{abstract}
Various corrosive agents affect and deteriorate the concrete whereas a release of major components as well as trace elements including heavy metals occurs. Microorganisms tend to colonize solid surfaces in natural environment by forming biofilm as a protective layer, and reducing that the exposure of the solid surface to the external environment. However, biofilm formation could also result in localized corrosion and deterioration of the substratum materials, such as mortars and concrete. Bio corrosion contributes significantly to a deterioration of the concrete structure. The paper aims at investigation of leaching the selected trace metals (cobalt and manganese), from cement mortars of different compositions, during a 180-day bacterial exposure.
\end{abstract}

Keywords: bio-corrosion, heavy metals, blast furnace slag, leaching

\section{Introduction}

The current trend of using secondary fuels for cement production and the use of secondary raw materials in the production of concrete and cement composite materials has drawn attention to leaching of environmentally hazardous substances, in particular toxic heavy metals, from construction of structures exposed to water $[1,2]$. Heavy metals in Portland cements in trace amounts occur commonly. Many elements are embedded in clinker matrix during clinker production or immobilized in hydration products of cement [3]. The presence of the heavy metals in the cement is related to the composition of

\footnotetext{
${ }^{1}$ Adriana Estokova, Technical University of Kosice, Faculty of Civil Engineering, Institute of Environmental Engineering, Vysokoskolska 4, 04200 Kosice, Slovakia, +421 55602 4265, adriana.estokova@tuke.sk

${ }^{2}$ Author for correspondence / autor do korespondencji: Michaela Smolakova, Technical University of Kosice, Faculty of Civil Engineering, Institute of Environmental Engineering, Vysokoskolska 4, 04200 Kosice, Slovakia, +421 55602 4297, michaela.smolakova@tuke.sk

${ }^{3}$ Alena Luptakova, Slovak Academy of Science, Institute of Geotechnics, Watsonova 45, 04353 Kosice, Slovakia, +421 557922 622, luptakal@saske.sk
} 
input raw materials but also to the used ones fuel, for example, waste materials used as secondary fuels may increase the input of metals into the firing process. According to [4], the heavy metals in the cement can be, depending on their origin, divided into several groups: antimony, manganese and vanadium are dominant of primary raw materials, indicating that for manganese up to $94 \%$ of its content in the cement originates in primary raw materials. Zinc and cadmium account for almost one half of their total content in cements to secondary fuels and secondary raw materials. Third group form metals such as cobalt and chromium, giving an equivalent share of secondary and primary raw material on the total metal content of the cement. In the case of cobalt, secondary raw materials from the production of iron and steel, ash, slag, but also secondary fuels, e.g. used tires are of importance. Lead and tin belonging to the fourth group originate almost exclusively from fuels and secondary raw materials. This categorization can also be applied to cements and cement composites while the waste-based admixtures clearly increase heavy metal content. This applies in particular to the blast furnace slag, which has been demonstrated increased content in particular of cadmium, chromium, manganese, tin, thallium and vanadium [4].

The concentration of metals in the clinker also depends on the conditions in the furnace and on the recirculation of metals in the furnace system [5]. The behavior of metals in the furnace system in the manufacture of cement depends on their volatility. Metals and their compounds which are non-volatile emerge from the furnace system in the predominant as part of a cement clinker, such as, for example, chromium and barium. Semi-metals and their compounds, e.g. lead and cadmium pass at sintering temperatures partially into the gas phase and then condense in the cooler portions of the feedstock. Volatile metals and their compounds (lead, thallium) that pass into the gas phase can condense on the raw material, to react with it, creating its own cycles or being emitted with the waste gas out with furnace [5]. The average content of cobalt in Portland cements varies about $10 \mathrm{ppm}$, manganese about $600 \mathrm{ppm}$. On the other hand, the content of those metals in cement composites with slag increases up to three times.

The metals present in the cement composites can be mobilised into the surrounding aqueous medium, which act on the material by direct leaching or dissolution and diffusion in the porous liquid. In principle, trace metals are directly leached into water adjacent to concrete surfaces by dissolution of surface phases and/or by dissolution and diffusion in the pore solution, the latter being affected by concrete porosity and pore structure. The solubility of trace metals depends on their bonding in the hydration products and other concrete constituents as well as their ability to form aqueous complexes and precipitate solubility-controlling phases. Thus, as observed by van der Sloot [6] for Cr, Mo, $\mathrm{Pb}$ and $\mathrm{Zn}$ in mortar, no general correlation exists between the total amount of trace metals and their availability [8]. 
In addition, microorganisms can play an important role in heavy metals leaching from concrete. In sewer systems, for example, the presence of sulfuric bacteria is linked to a biotic corrosion of concrete [7]. Acidithiobacillus thiooxidans bacteria have been shown to play a key role in the process of oxidation of hydrogen sulphide to sulphuric acid and thus contribute to the deterioration of materials [8,9]. These sulphur-oxidizing microorganisms produce sulphuric acid, which leads to the $\mathrm{pH}$ reduce of concrete to 9 or less, and thus to favourable conditions for massive settlement of surfaces with other bacteria [10]. In that case, other degradative chemical processes are also taking place, which can result in excessive release of heavy metals into the environment. Leaching of chromium, barium or cadmium from cement composites has been given attention in many works. This work is dealt with the leaching of less studied heavy metals such as cobalt and manganese, of cement mortars with different blast furnace portions, during 180 days of exposure to bacteria A. thiooxidans.

\section{Material and Methods}

Table 1 shows the composition of the mixes used in the experiments. Sample R0 represented the reference sample without any addition of slag, samples S1, S2, S3 and S4 represented the samples with different share of blast furnace slag.

Table 1. Composition of the mortar samples

Tabela 1. Skład próbek zaprawy

\begin{tabular}{|c|c|c|}
\hline \multirow{2}{*}{ Mortar Sample } & CEM I & GGBS \\
\cline { 2 - 3 } & (wt. \%) & (wt. \%) \\
\hline R0 & 100 & 0 \\
\hline S1 & 35 & 65 \\
\hline S2 & 25 & 75 \\
\hline S3 & 15 & 85 \\
\hline S4 & 5 & 95 \\
\hline
\end{tabular}

The prepared cement mortars samples were placed in biotic liquid medium at temperature of $25^{\circ} \mathrm{C}$ over a period of 180 days. The biotic environment was simulated by $A$. thiooxidans, which was isolated from an acid mine drainage from Pech shaft (locality of Smolnik, Eastern Slovakia). Elemental sulphur was added to the nutrient medium to ensure the growth of bacteria. After placing samples into liquid medium $(\mathrm{pH}=4)$ for the leaching experiment, a chemical composition of concrete samples' leachates and $\mathrm{pH}$ of liquid medium were investigated periodically. 
$\mathrm{X}$-ray fluorescence analysis (XRF) was used to analyse the chemical composition of leachates. SPECTRO iQ II (Ametek, Germany) with SDD silicon drift detector with resolution of $145 \mathrm{eV}$ at 10000 pulses was used for the analysis. The primary beam was polarized by Bragg crystal and Highly Ordered Pyrolytic Graphite - HOPG target. The samples were measured during $180 \mathrm{~s}$ at voltage of $25 \mathrm{kV}$ and $50 \mathrm{kV}$ at current of 0.5 and $1.0 \mathrm{~mA}$ under helium atmosphere by using the standardized method of fundamental parameters for liquids. $\mathrm{pH}$ changes were measured by $\mathrm{pH}$ meter FG2- FiveGo (Mettler-Toledo, Switzerland) [11].

\section{Results and Discussion}

\section{1. $\mathrm{pH}$ evolution}

The evolution of $\mathrm{pH}$ in samples leachates, during the bio-corrosion experiment is reported in Fig. 1.

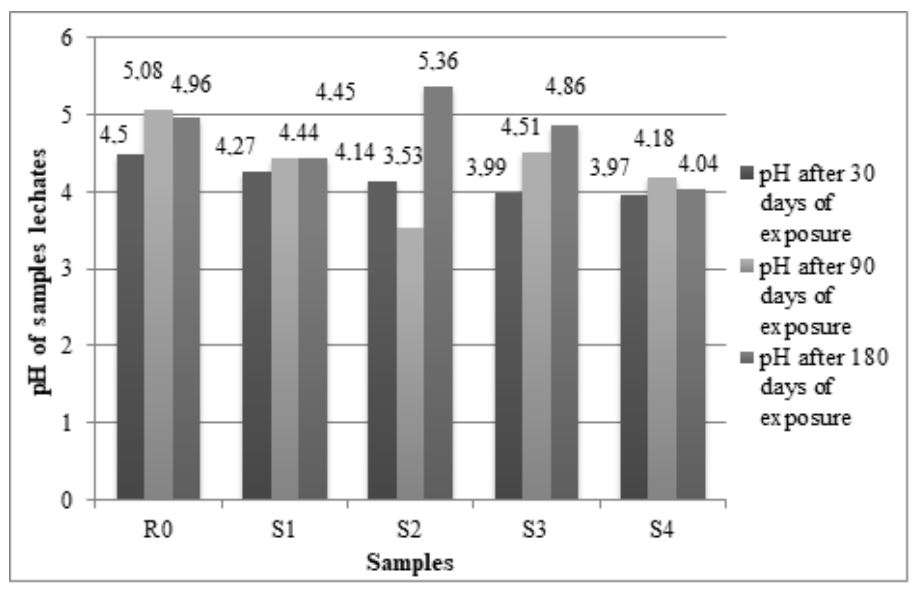

Fig. 1. $\mathrm{pH}$ values after the individual periods

Rys. 1. Wartości pH po poszczególnych okresach

As is clear from Fig. 1, the $\mathrm{pH}$ in the samples' leachates ranged from 3.53 5.36 after the individual leaching periods whereas slightly differed from the original one $(\mathrm{pH}=4)$. The $\mathrm{pH}$ changes were connected to two processes: 1) production of the biogenic sulphuric acid by bacterial activity and 2) dissolution of the alkaline components of the cement matrix. The first process tends to decrease in $\mathrm{pH}$ values while the second one, on the contrary, to the increase in $\mathrm{pH}$. The measured values after the individual leaching periods documented what process was likely the dominant one. The raise of $\mathrm{pH}$ values was observed for all leachates with the exception of sample S2 after 30 days of the experiment. 
However, the observed $\mathrm{pH}$ values were much lower than those of found of the chemical-based sulphuric acid corrosion [12]. That finding confirmed a different course of biogenic and chemical corrosion as mentioned in [13]. Not considering the S2 sample, the highest $\mathrm{pH}$ values were measured for the reference sample $\mathrm{R} 0$, indicating the most intensive leaching of the basic components of the cement composite.

\subsection{Mn and Co concentrations}

The occurrence of cobalt in the aquatic environment depends on the $\mathrm{pH}$ value of the environment. Above the $\mathrm{pH}=6$, cobalt exists in the form of its stable salts, such as $\mathrm{CoCO}_{3}, \mathrm{Co}(\mathrm{OH})_{2}$, and $\mathrm{Co}_{3} \mathrm{O}_{4}$. Under highly alkaline conditions, the cobalt ions are found in the soluble form of the $\mathrm{HCoO}_{2}$. Similarly, in acidic media below $\mathrm{pH}=6$ the $\mathrm{Co}^{2+}$ ions are also present in their soluble compounds. The $\mathrm{pH}$ range $3.5-5.4$, measured in the analysed liquid media, was therefore suitable to dissolve the cobalt compounds and release the cobalt ions into the solution. The measured concentrations of $\mathrm{Co}^{2+}$ ions in the yields of the individual cement composites are shown in Fig. 2.

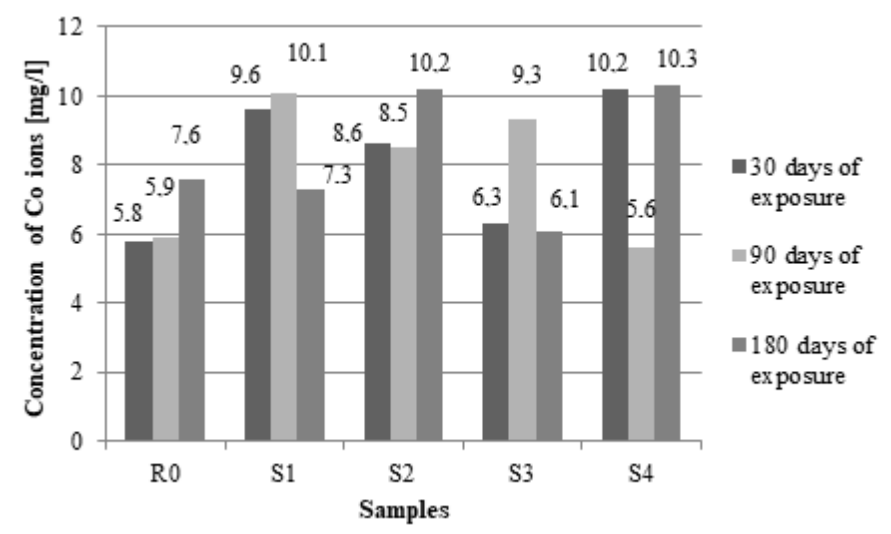

Fig. 2. Leaching trends of $\mathrm{Co} 2+$ ions

Rys. 2. Trendy wypłukiwania jonów Co2+

The most intensive leaching of Co ions after 180 days was observed for the samples $\mathrm{S} 4(10.3 \mathrm{mg} / \mathrm{L})$ and $\mathrm{S} 2(10.2 \mathrm{mg} / \mathrm{L})$, exposed to bacteria (Fig. 2). The highest concentration of $\mathrm{Co}^{2+}$ ions after 90 days of exposure $(10.1 \mathrm{mg} / \mathrm{L})$ was observed for sample S1. Except for the reference sample, no dependence of leached-out quantity of cobalt on the leaching time was observed for any sample. Significant fluctuations in $\mathrm{Co}^{2+}$ concentrations in the leachates, for individual samples, during the experiment could be likely related to the formation of new compounds in the solution and the incorporation of cobalt into their structure 
and subsequent precipitation of those on the surface or in the pores of the composite as is known for calcium compounds. Originally, the cobalt matrix may be present in several hydration products, in particular as sorbate on monosulfate (AFm) or as part of tobermorite [4]. Comparing the measured $\mathrm{Co}^{2+}$ leached-out quantities regarding the samples composition, the amount of dissolved cobalt do not correlate with the slag content in mortars in any way.

The changes of manganese concentrations in leachates during the 180-day experiment are illustrated in Fig. 3.

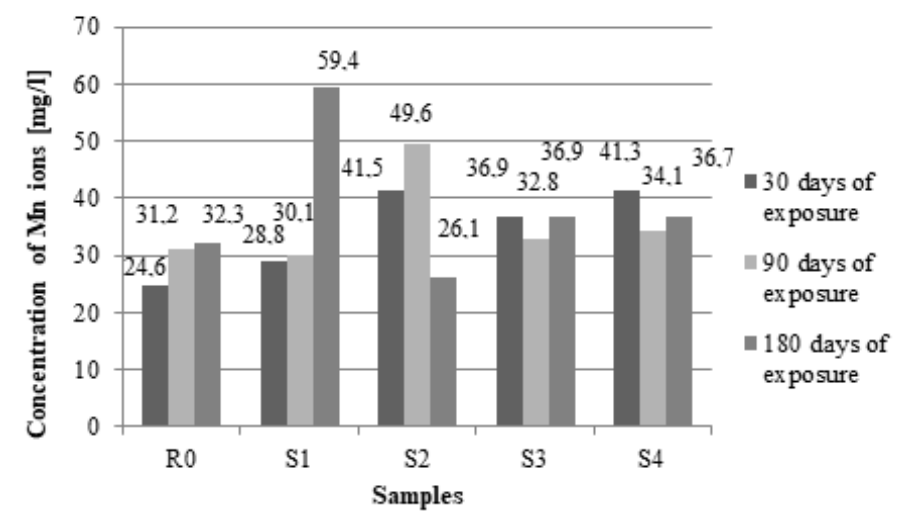

Fig. 3. Leaching trends of Mn ions

Rys. 3. Trendy wypłukiwania jonów Mn

The highest concentration of $\mathrm{Mn}$ ions $(59.4 \mathrm{mg} / \mathrm{L})$ was measured in leachate of sample S1 after 180 days of bacterial exposure. No correlation of leached-out amounts of manganese versus slag content in cement mortars was found as well.

\section{Conclusion}

Leaching of major and trace elements is always associated to the degradation of cement paste, due dissolution of the hydration products. Results on the leaching of Co and Mn from cement mortars did not prove any clear relation between the composition of cement mortars and the leaching of the metals mentioned. Since no significant trends of Co and Mn leaching were noticed, it could be interesting to monitor these indicators over a longer period of time.

\section{Acknowledgements}

The research was supported by the Grant No. 2/0145/15 of the Slovak Grant Agency for Science. 


\section{Bibliography}

[1] Hohberg I. Charakterisierung, Modellierung und Bewertung des Auslaugverhaltens umweltrelevanter, anorganischer Stoffe aus zementgebundenen Baustoffen/ Characterization, modelling and assessment of the leaching behaviour of environmentally relevant inorganic compounds from cement based building materials. Deutscher Ausschuss für Stahlbeton. Wilhelm Ernst \& Sohn, Is. 542, 2003.

[2] Müllauer W., Beddoe R.E., Heinz D. Leaching behaviour of major and trace elements from concrete: effect of fly ash and GGBS. Cement and Concrete Composites. Vol. 58. pp. 129-139, 2015.

[3] Magistri M., Recchi P. and Bravo A. Parameters Influencing The Leachability of Antimony From Hardened Concrete. 2013.

[4] Achternbosch, M. et al.: Heavy metals in cement and concrete resulting from the coincineration of wastes in cement kilns with regard to the legitimacy of waste utilisation. Karlsruhe: Forschungszentrum Karlsruhe GmbH 2003.

[5] Reference Documents on Best Available Techniques in the Cement, Lime and Magnesium Oxide Manufac-turing Industries [online]. In: European Commission: May 2010. ftp://ftp.jrc.es/pub/eippcb/doc/clm_bref_0510.pdf.

[6] Van der Sloot H.A. Comparison of the characteristic leaching behavior of cements using standard (EN 196-1) cement mortar and an assessment of their long-term environmental behavior in construction products during service life and recycling. Cement and Concrete Research Vol. 30. No 7 pp. 1079-1096, 2000.

[7] Yoshida N., Morinaga T., Murooka, Y. Characterization and identification of bacterial strains isolated from corroded concrete in the accumulation stratum and their resistance levels to heavy metals. Journal of fermentation and bioengineering Vol. 76. No. 5 pp. 400-402, 1993.

[8] Jensen H.S., Nielsen A.H., Hvitved-Jacobsen T., Vollertsen J. Survival of hydrogen sulfide oxidizing bacteria on corroded concrete surfaces of sewer systems. Water Science and Technology Vol. 57. No. 11 pp. 1721-1726, 2008.

[9] Kelly D.P., Wood A.P. Reclassification of some species of Thiobacillus to the newly designated genera Acidithiobacillus gen. nov., Halothiobacillus gen. nov. and Thermithiobacillus gen. nov. International Journal of Systematic and Evolutionary Microbiology Vol. 50. No. 2 pp. 511-516, 2000.

[10] Joseph A.P., Keller J., Bustamante H., Bond P.L. Surface neutralization and $\mathrm{H}_{2} \mathrm{~S}$ oxidation at early stages of sewer corrosion: influence of temperature, relative humidity and $\mathrm{H}_{2} \mathrm{~S}$ concentration. Water research Vol. 46. No. 13 pp. 4235-4245, 2012.

[11] Jiang G., Wightman E., Donose B.C., Yuan Z., Bond P.L., Keller J. The role of iron in sulfide induced corrosion of sewer concrete. Water research Vol. 49, pp. 166-174, 2014.

[12] Ondrejka Harbulakova V., Stevulova N., Repka M., Luptakova A. Study of different types of corrosion processes simulated in model conditions. Budownictwo i inzynieria środowiska. Vol. 59. No. 1 pp. 141-148, 2012.

[13] Kovalcikova M., Estokova A., Luptakova A. Application of Granulated Blast Furnace Slag in Cement Composites Exposed to Biogenic Acid Attack. IOP Conference Series: Materials Science and Engineering. Vol. 96. No. 1 pp. 012014, 2015. 


\section{TENDENCJE WYPLUKIWANIA Co ORAZ Mn ZE SPOIW ŻUŻLOWYCH}

\section{Streszczenie}

Różne czynniki korozyjne wpływają i pogarszają beton, podczas gdy występuje uwalnianie różnych składników, w tym metali ciężkich, występuje. Mikroorganizmy mają tendencję do kolonizacji stałych powierzchni w środowisku naturalnym, tworząc biofilm jako warstwę ochronną. Jednakże, tworzenie biofilm może również powodować miejscowe występowanie korozji oraz zniszczenie materiałów podłoża, takich jak zaprawy i betonu. Korozja biologiczna w znacznym stopniu przyczynia sie do pogorszenia struktury betonu. Celem pracy jest zbadanie procesu wypłukiwania wybranych metali śladowych (kobaltu i manganu) z zapraw murarskich różnych kompozycji podczas 180-dniowego narażenia na działanie bakterii.

Słowa kluczowe: biokorozja, metale ciężkie, żużel wielkopiecowy, wypłukiwanie

Przestano do redakcji: $24.09 .2017 \mathrm{r}$.

Przyjęto do druku: 15.12.2017 r. 